\title{
The prevalence of musculoskeletal diseases among casual dock workers
}

\author{
Marlise Capa Verde de Almeida ${ }^{1}$ \\ Marta Regina Cezar-Vaz ${ }^{2}$ \\ Jorgana Fernanda de Souza Soares ${ }^{3}$ \\ Mara Regina Santos da Silva ${ }^{2}$
}

This study identified the prevalence of work-related musculoskeletal disorders among casual dockworkers. This is a retrospective and quantitative study, the data sources of which included the medical files of dockworkers from 2000 to 2009. Data were collected in a medical service for dockworkers using a previously developed form; descriptive quantitative analysis was performed. Ethical aspects were complied with. A total of $15.8 \%$ of the diagnoses identified among male workers referred to musculoskeletal disorders. Individuals older than 52 years of age and with more than 21 years working in the field predominated. The most frequent musculoskeletal diseases included low back pain $(38.8 \%)$, tendinitis $(19.7 \%)$, and neck pain (12.5\%). These diseases can be prevented through health interventions, confirming the importance of developing clinical support in nursing in order to improve the quality of life of dockworkers.

Descriptors: Public Health Nursing; Occupational Health; Cumulative Trauma Disorders.

${ }^{1}$ Doctoral student, Universidade Federal do Rio Grande, Brazil.

2 PhD, Associate Professor, Escola de Enfermagem, Universidade Federal do Rio Grande, Brazil.

${ }^{3}$ Doctoral student, Universidade Federal da Bahia, Brazil. Scholarship holder of the Conselho Nacional de Desenvolvimento Científico e Tecnológico (CNPq).

Corresponding Author:

Marlise Capa Verde de Almeida

Universidade Federal do Rio Grande

Rua Almirante Barroso, 197, Apto. 208

Bairro: Centro

CEP: 96201-001, Rio Grande, RS, Brasil

E-mail: marlisealmeida@msn.com 


\section{Prevalência de doenças musculoesqueléticas entre trabalhadores portuários avulsos}

O objetivo deste estudo foi identificar a prevalência de doenças musculoesqueléticas relacionadas ao trabalho, entre trabalhadores portuários avulsos. É estudo quantitativo, retrospectivo. A fonte de dados constituiu-se de fichas de atendimento médico dos trabalhadores portuários avulsos, no período de 2000 a 2009. A coleta de dados foi realizada em um serviço de medicina do trabalho portuário, a partir de formulário pré-determinado. Procedeu-se à análise quantitativa descritiva. Aspectos éticos foram respeitados. Identificaram-se $15,8 \%$ de diagnósticos de doenças osteomusculares, entre trabalhadores do sexo masculino. Predominaram indivíduos com mais de 52 anos de idade e com tempo de atuação laboral superior a 21 anos. As doenças osteomusculares prevalentes foram lombalgias (38,8\%), tendinites $(19,7 \%)$ e cervicalgias $(12,5 \%)$, que podem ser prevenidas por meio de ações interventoras em saúde, ratificando a importante construção de subsídios clínicos em enfermagem para a qualidade do trabalho portuário.

Descritores: Enfermagem em Saúde Pública; Saúde do Trabalhador; Transtornos Traumáticos Cumulativos.

\section{Prevalecía de enfermedades musculoesqueléticos entre trabajadores portuarios apulsos}

Este estudio tuvo como objetivo identificar la prevalecía de enfermedades osteomusculares relacionadas al trabajo entre trabajadores portuarios sin registro. Estudio cuantitativo, retrospectivo. La fuente de datos las tablas de atención medica de los trabajadores portuarios sin registro en el período de 2000 a 2009. La colecta de datos fue realizada en un Servicio de Medicina del Trabajo Portuario a partir de un formulario predeterminado. Se procedió en el análisis cuantitativo descriptivo de los datos. Los aspectos éticos fueran respetados. Se identificó $15,8 \%$ diagnósticos de enfermedades osteomusculares, entre trabajadores del sexo masculino. Predominaran individuos con más de 52 años de edad y con tiempo de actuación laboral superior a 21 años. Las principales enfermedades fueran de lumbalgia $(38,8 \%)$, tendinitis $(19,7 \%)$ y cervicalgía $(12,5 \%)$. Las enfermedades osteomusculares mas prevalentes fueran las lumbalgías, tendinitis y cervicalgías, las cuales pueden prevenirse por medio de acciones interventoras y evaluativas en salud, ratificando la importancia de construir subsidios clínicos en enfermería que colaboren para la cualidad de vida del trabajador portuario.

Descriptores: Enfermería en Salud Pública; Salud Laboral; Trastornos de Traumas Acumulados.

\section{Introduction}

The organizational and structural elements that compose the context of labor in society can either benefit human life or harm the health of workers leading to the onset of significantly frequent pathologies such as Repetitive Strain Injury (RSI), the recently denominated Work-Related Musculoskeletal Diseases $(\text { WRMD })^{(1)}$, Cumulative Trauma Disorders (CTD), and Musculoskeletal diseases.
This group of diseases is characterized by the occurrence of symptoms such as pain, numbness, feeling of heaviness and fatigue, which generally occurs in an insidious manner, especially in the upper limbs, though it can also affect the lower limbs(2). Diseases develop due to excessive overload on muscles exposed to repetitive movements and localized strain, as well as in the case of work under whole-body vibration 
and when it is necessary to keep the arms above the shoulders region(2). These conditions are usually caused by repetitive movements that exceed the resilience of the components of the locomotor system, such as bones, tendons, ligaments, and muscles. These are often associated with inappropriate work conditions and psychosocial factors.

In general, the occurrence of this group of diseases is associated with operational and organizational changes, a consequence of the implementation of new production technologies that lead to changes in the work structure and includes in the process new devices that affect the workers' quality of life and productive capacity and results, among other things, in absenteeism ${ }^{(3)}$.

Among the various productive areas of important economic representation in Brazil and in the world is the work performed in seaports, which through shipping, transportation of passengers or transportation and storage of goods, is a strategy for economic growth in cities where these ports are located and for the country in general ${ }^{(4)}$.

Most of the port activities that take place in companies operating in seaports are performed by casual dockworkers, so-called because, even though they are permanent workers, their work has a casual nature and is not ruled by a work contract, and is necessarily mediated by Workforce Management Agencies( ${ }^{(5)}$. These workers develop six types of activities: wharfage, stevedoring, cargo checking, cargo repairing, surveillance of vessels, and block workers who's work routines include a heterogeneous occupational exposure, intensified by the principle of multifunctionality ${ }^{(5)}$. According to this principle, workers from different professions can perform distinct activities and tasks requiring the same qualifications, regardless of their profession.

The routine activities concerning port work expose individuals to situations that are harmful to health and conducive to diseases, such as inappropriate places where harmful cargo and material, like toxic and radioactive material, is handled, stored and transported; exposure to noise; vibrations of machines; inclement weather; contact with chemical substances; and inadequate work tools, among others, which determine these workers' health-disease continuums ${ }^{(2,6)}$.

Ergonomic and psychosocial exposure also stands out in the context of the work performed in seaports. Inappropriate posture, intense work performed in shifts and involving repetitive tasks and movements, performed under psychological pressure, demanding the rapid acquisition of qualifications, training, and adaptation can be determinant in the onset of musculoskeletal disease.

The incidence of these diseases among casual dockworkers has been addressed in other studies ${ }^{(7-8)}$, which emphasize the weight of loads to be handled and unloaded from inside holds and decks of vessels as potential causes for this groups of diseases. The group of musculoskeletal disorders was the most frequently reported by these workers ${ }^{(8)}$.

Therefore, there is a need for studies addressing this subject, especially in the context of work in seaports. Delimiting the profile of morbidity among casual dockworkers can support nursing interventions in an important field of health practice, aiming to prevent such conditions. Additionally, scientific production within the field of nursing concerning this subject in other contexts of labor is incipient; it often addresses nursing workers affected by these pathologies ${ }^{(1,3,9-11)}$. Investigating other labor contexts is important in order to deepen knowledge in the field of Public Health Nursing.

Hence, this study's objective was to identify the prevalence of work-related musculoskeletal diseases among casual dockworkers.

\section{Method}

This quantitative, descriptive and retrospective study was conducted in a seaport in the South of Brazil. Data sources included medical files from the Port Work Medicine Outpatient Clinic belonging to the Work Management Agency of Casual Port Work in this seaport.

A form was developed based on recommendations provided by the Brazilian Ministry of Health, other instruments used in occupational health, and information contained in the medical files themselves- obtained through previous contact with the data source- to collect data ${ }^{(2,6)}$.

The data collection instrument comprised four sessions: characterization of the subjects, clinical data and medical diagnoses, health actions implemented by the professionals, and actions focused on evaluating the workers' health conditions when returning to work. The following variables were used: age, work experience, lifestyle, profession, race, lower back pain, lumbar sciatic pain, pain in the upper back, neck pain, arthroses, joint pain, arthritis, tendinitis, epicondylitis, bursitis, synovitis, tenosynovitis, and trigger finger. The records included all the diagnosed musculoskeletal diseases. Workers may present more than one related disease within the period of data collection, from 2000 to 2009.

The data were double entered in the EPINFO 6.04 program, ensuring a clean and organized database. Then, 
the data were imported into the Statistical Package for the Social Sciences (SPSS), version 13.0, for descriptive statistical analysis, which included the computation of proportions and Person's Chi-square test. The level of significance was fixed at $\alpha=0.05$.

The study project entitled "Health, Risks, and Occupational Diseases - An integrated study in different workplaces", of which this study is part, was submitted to and approved by the Ethics Research Committee at the FURG, protocol 109/2010. Authorization was also asked from the Workforce Management Agency in Rio Grande, Brazil. Additionally, the researchers involved in the study ensured confidentiality of collected data.

\section{Results}

A total of 953 files from the Port Work Medicine Outpatient Clinic were consulted; two $(0.2 \%)$ files did not report the activity performed by the worker. Of the 951 consulted files, 152 were selected. These involve workers affected by musculoskeletal diseases: 73 (48\%) were wharf workers, 57 (37.5\%) longshoremen,
$10(6.6 \%)$ guarded vessels, nine $(5.9 \%)$ were cargo checkers, two (1.3\%) block workers, and one $(0.7 \%)$ was a cargo repairman.

All the selected files belonged to male casual dockworkers; 77 (50.7\%) were older than 52 years of age; and 88 (57.9\%) workers had more than 21 years experience. Records indicate that 116 (76.3\%) individuals were Caucasian, and concerning lifestyle, 32 $(34.2 \%)$ were smokers, while 14 (9.2\%) were alcoholics.

A total of 170 diagnoses were identified, indicating that 15 workers presented more than one pathological disease. The most frequent conditions were lower back pain with $59(38.8 \%)$ cases, tendinitis accounted for $30(19.7 \%)$ cases, and neck pain affected $19(12.5 \%)$ workers. The three pathologies together accounted for more than half of the identified cases (71\%).

Wharf work was the activity with the highest number of cases $(\mathrm{N}=84)$, followed by longshoremen $(\mathrm{N}=61)$, and cargo checkers $(\mathrm{N}=11)$, while block workers and cargo repairmen were those with the lowest number of diagnoses and records in the medical files (Table 1 ).

Table 1 - Frequency of work-related musculoskeletal pathologies diagnosed according to professional activity. Rio Grande, RS, Brazil, 2010

\begin{tabular}{|c|c|c|c|c|c|c|c|c|c|c|c|c|}
\hline & \multicolumn{2}{|c|}{$\begin{array}{c}\text { Lower back } \\
\text { pain }\end{array}$} & \multicolumn{2}{|c|}{$\begin{array}{l}\text { Pain upper } \\
\text { back }\end{array}$} & \multicolumn{2}{|c|}{ Arthroses } & \multicolumn{2}{|c|}{ Tendinitis } & \multicolumn{2}{|c|}{ Epicondylitis } & \multicolumn{2}{|c|}{ Bursitis } \\
\hline & $n$ & $\%$ & $n$ & $\%$ & $n$ & $\%$ & $\mathrm{n}$ & $\%$ & $n$ & $\%$ & $\mathrm{n}$ & $\%$ \\
\hline \multicolumn{13}{|c|}{ Professional activity } \\
\hline Wharf workers & 32 & $21.1 \%$ & 2 & $1.3 \%$ & 10 & $6.6 \%$ & 16 & $10.5 \%$ & 7 & $4.6 \%$ & 2 & $1.3 \%$ \\
\hline Longshoremen & 20 & $13.2 \%$ & 3 & $2.0 \%$ & 4 & $2.6 \%$ & 6 & $3.9 \%$ & 5 & $3.3 \%$ & 5 & $3.3 \%$ \\
\hline Checkers & 5 & $3.3 \%$ & $0 \%$ & & $0 \%$ & & 1 & $0.7 \%$ & 1 & $0.7 \%$ & $0 \%$ & \\
\hline Repairmen & $0 \%$ & & $0 \%$ & & $0 \%$ & & $0 \%$ & & $0 \%$ & & $0 \%$ & \\
\hline Guards & 1 & $0.7 \%$ & $0 \%$ & & $0 \%$ & & & $4.6 \%$ & $0 \%$ & & $0 \%$ & \\
\hline Block workers & 1 & $0.7 \%$ & $0 \%$ & & 1 & $0.7 \%$ & $0 \%$ & & $0 \%$ & & $0 \%$ & \\
\hline Total & 59 & & 5 & & 14 & & 30 & & 13 & & 7 & \\
\hline \multicolumn{13}{|l|}{ Age range } \\
\hline$<52$ & 26 & $17.1 \%$ & 3 & $2.0 \%$ & 6 & $3.9 \%$ & 22 & $14.5 \%$ & 6 & $3.9 \%$ & 2 & $1.3 \%$ \\
\hline$>52$ & 33 & $21.7 \%$ & 2 & $1.3 \%$ & 9 & $5.9 \%$ & & $5.3 \%$ & 7 & $4.6 \%$ & 5 & $3.3 \%$ \\
\hline \multicolumn{13}{|l|}{ Experience } \\
\hline$<21$ & 35 & $23 \%$ & 2 & $1.3 \%$ & 6 & $3.9 \%$ & 21 & $13.8 \%$ & 5 & $3.3 \%$ & 3 & $2.0 \%$ \\
\hline \multirow[t]{3}{*}{$>21$} & 24 & $15.8 \%$ & 3 & $2.0 \%$ & 9 & $5.9 \%$ & & $5.9 \%$ & 8 & $5.3 \%$ & 4 & $2.6 \%$ \\
\hline & \multicolumn{2}{|c|}{ Synovitis } & \multicolumn{2}{|c|}{ Trigger finger } & \multicolumn{2}{|c|}{ Neck pain } & \multicolumn{2}{|c|}{$\begin{array}{l}\text { Lumbar } \\
\text { sciatic pain }\end{array}$} & \multicolumn{2}{|c|}{ Arthritis } & \multicolumn{2}{|c|}{ Joint pain } \\
\hline & $\mathrm{n}$ & $\%$ & $\mathbf{n}$ & $\%$ & $\mathrm{n}$ & $\%$ & $\mathrm{n}$ & $\%$ & $\mathrm{n}$ & $\%$ & $\mathrm{n}$ & $\%$ \\
\hline \multicolumn{13}{|c|}{ Professional activity } \\
\hline Wharf workers & 1 & $0.7 \%$ & $0 \%$ & & 9 & $5.9 \%$ & 3 & $2.0 \%$ & 1 & $0.7 \%$ & 1 & $0.7 \%$ \\
\hline Longshoremen & 2 & $1.3 \%$ & 1 & $0.7 \%$ & 7 & $4.6 \%$ & 4 & $2.6 \%$ & 2 & $1.3 \%$ & 2 & $1.3 \%$ \\
\hline Checkers & $0 \%$ & & $0 \%$ & & $0 \%$ & & 3 & $2.0 \%$ & $0 \%$ & & 1 & $0.7 \%$ \\
\hline Repairmen & $0 \%$ & & $0 \%$ & & $0 \%$ & & 1 & $0.7 \%$ & $0 \%$ & & $0 \%$ & \\
\hline Guards & $0 \%$ & & $0 \%$ & & 2 & $1.3 \%$ & $0 \%$ & & $0 \%$ & & $0 \%$ & \\
\hline Block workers & $0 \%$ & & $0 \%$ & & 1 & $0.7 \%$ & $0 \%$ & & $0 \%$ & & $0 \%$ & \\
\hline Total & 2 & & 1 & & 19 & & 11 & & 15 & & 4 & $2.6 \%$ \\
\hline
\end{tabular}


Table 1 - (continuation)

\begin{tabular}{|c|c|c|c|c|c|c|c|c|c|c|c|c|}
\hline & \multicolumn{2}{|c|}{ Synovitis } & \multicolumn{2}{|c|}{ Trigger finger } & \multicolumn{2}{|c|}{ Neck pain } & \multicolumn{2}{|c|}{$\begin{array}{l}\text { Lumbar } \\
\text { sciatic pain }\end{array}$} & \multicolumn{2}{|c|}{ Arthritis } & \multicolumn{2}{|c|}{ Joint pain } \\
\hline & $\mathbf{n}$ & $\%$ & $\mathbf{n}$ & $\%$ & $\mathrm{n}$ & $\%$ & $\mathbf{n}$ & $\%$ & $\mathbf{n}$ & $\%$ & $\mathbf{n}$ & $\%$ \\
\hline \multicolumn{13}{|c|}{ Age range } \\
\hline$<52$ & 3 & $2.0 \%$ & 0 & & 11 & $7.2 \%$ & 3 & $2.0 \%$ & 1 & $0.7 \%$ & $0 \%$ & \\
\hline$>52$ & $0 \%$ & & 1 & $0.7 \%$ & 8 & $5.3 \%$ & 8 & $5.3 \%$ & 2 & $1.3 \%$ & 4 & $2.6 \%$ \\
\hline \multicolumn{13}{|c|}{ Experience } \\
\hline$<21$ & 2 & $1.3 \%$ & 1 & $0.7 \%$ & 12 & $7.9 \%$ & 3 & $2.0 \%$ & 2 & $1.3 \%$ & 1 & $0.7 \%$ \\
\hline$>21$ & 1 & $0.7 \%$ & $0 \%$ & & 7 & $4.6 \%$ & 8 & $5.3 \%$ & 1 & $0.7 \%$ & 3 & $2.0 \%$ \\
\hline
\end{tabular}

The statistical test revealed a dependency relationship between the variables 'professional activity' and 'tendinitis' $(p=0,001)$, which was statistically significant in relation to the activity 'guards vessels'. The occurrence of 'lumbar sciatic pain' $(p=0.033)$ was significantly associated with 'cargo checkers'. Additionally, the diagnosis of tendinitis was significantly associated with age $(p=0.006)$; the most significant age range was below 52 years of age. The diagnosis of 'lumbar sciatic pain' was statistically significant in association with the variable 'work experience' $(p=0.033)$; the variable 'more than 21 years of work experience' presented the highest significance.

In regard to the sites at which musculoskeletal diseases manifested, the records frequently indicated upper limbs $(\mathrm{N}=25)$, especially for the occurrence of tendinitis; lower limbs $(\mathrm{N}=21)$ for the occurrence of arthroses and joint pain; trunk $(\mathrm{N}=22)$ for the occurrence of upper back pain and bursitis; and a nonspecific description of the site affected by the pathology $(\mathrm{N}=31)$, as shown by Table 2 .

Table 2 - Distribution of frequencies concerning the diagnoses of work-related musculoskeletal diseases according to sites. Rio Grande, RS, Brazil, 2010

\begin{tabular}{|c|c|c|c|c|c|c|}
\hline Musculoskeletal diseases & Upper limbs & Lower limbs & Trunk & Ignored & Total & $\%$ \\
\hline Upper back pain (M54) & 0 & 0 & 10 & 13 & 26 & 15.8 \\
\hline Lower back pain & - & - & - & - & 59 & 38.8 \\
\hline Other arthroses (M19.0) & 3 & 8 & 2 & 1 & 15 & 9.9 \\
\hline Shoulder lesions (M75) & 16 & 7 & 5 & 4 & 30 & 19.7 \\
\hline Other enthesopathies (M77) & 4 & - & - & 9 & 13 & 8.6 \\
\hline Soft tissue disorders (M70) & 1 & 1 & 3 & 2 & 7 & 4.6 \\
\hline Synovitis and tenosynovitis (M65) & 1 & 1 & 1 & - & 3 & 2.0 \\
\hline Trigger finger (M65.3) & - & - & - & - & 1 & 0.7 \\
\hline \multicolumn{7}{|c|}{ Non work-related conditions } \\
\hline Joint pain & - & 3 & - & 1 & 4 & 2.6 \\
\hline Arthritis & - & 1 & 1 & 1 & 3 & 2.0 \\
\hline Lumbar sciatic pain & - & - & - & - & 11 & 7.2 \\
\hline
\end{tabular}

In addition to the conditions already mentioned, other conditions were also observed, though with a lower frequency, such as arthroses, enthesopathy (such as epicondylitis), bursitis, synovitis, tenosynovitis, and a single case of trigger finger, which totaled 39 cases (25.8\%). There were also occurrences of unknown work-related pathologies, totaling 18 cases (11.8\%).

\section{Discussion}

The results highlight that musculoskeletal diseases affect port workers and these conditions should be the focus of interventions aiming to improve the quality of life of casual port workers. The results revealing that workers are affected by musculoskeletal diseases corroborate the reports of workers addressed in a previous study(8). 
The labor activities performed in a seaport require the manual handling of heavy loads, which in turn demand the physical strain of several muscle groups. Additionally, equipment such as vehicles, tractors, and mechanical shovels are frequently used, which exposes workers to whole-body vibration for virtually the entire work period. Such conditions, coupled with the fact that tasks are performed while in a sitting position, arms maintained above shoulder-level, and a lack of regular exercise, contribute to the development of RSI/WRMD(1-2).

This study shows that in this context wharf workers, longshoremen, and vessel guards are those most affected by pathologies of this organic group ${ }^{(8)}$, confirming previous health information. Among the diseases identified, lower back pain was the most frequent and affected wharf workers and longshoremen, the activities of whom are the most representative in the sample.

The literature suggests that worker age is an important factor in the development of chronic lower back pain (2), however, association among these variables was not significant in this study. Such a result may suggest there are other reasons for the development of these conditions, such as those related to working conditions and characteristics. In wharf work, these characteristics include transporting goods on the docks with the use of machines such as forklifts, tractors, automotive vehicles, belonging to the port service itself or to the ships(5).

It is worth noting that the role of whole-body vibrations in lower back pain is intensified according to the magnitude of vibrations in work machines, depending on the type and time of exposure, human discomfort, and the potential onset of musculoskeletal diseases ${ }^{(12)}$.

A similar situation occurs with longshoremen. This is the second most affected class of workers, whose work characteristics are similar to those of wharf work. The difference is that these are performed inside vessels, such as in the decks and holds of ships. An additional factor in this context refers is that not all casual dockworkers performing both activities have the technical habilitation to operate the machines, which can impede rotation among workers in the work with the machines, not complying with the need to reduce the time of exposure to vibration for individual workers, one of the most efficient measures to alleviate the occurrence of lower back pain and occupational diseases arising from this exposure(2).

Recent studies report of the existence of techniques able to ease the painful symptoms of lower back pain without the use of medication, such as regular ergonomic exercises in order to broaden the amplitude of joint movements and improve muscle results, in addition to physical therapy techniques such as Muscle Energy and Dynamic Muscular Reeducation(13-14).

In addition to these techniques, a nursing examination to assess the amplitude of the movement of body segments ${ }^{(15)}$ is argued to be an efficient measure to detect musculoskeletal disorders that may lead to an inability to work. The implementation of these actions may delay the conditions' onset and also lead to the early identification of painful sites so that preventive measures are taken.

Lower back pain also leads to postural instability ${ }^{(13)}$, which may cause irreversible damage to workers who perform their activities at a height and are at risk of falling into the sea, such as when lashing* or unlashing cargo. Both activities are often performed on top of loads and equipment (i.e. containers, cellulose). Therefore, the work of individuals affected by these conditions may increase the risk of occupational accidents and the onset of work-related pathologies.

Another condition that stood out was tendinitis, a type of disease classified among shoulder lesions, which causes intense pain and limits movement in different segments of the affected limbs, changing according to the position in which one applies physical exertion(2).

Many conditions related to tendinitis tend to affect the shoulder region, which is formed by the supraspinatus, infraspinatus, subcapularis, and deltoid muscles and their respective tendons, whose function is to stabilize the movement of the shoulders ${ }^{(2)}$. These factors are once again observed among wharf workers and longshoremen, who present the following diagnoses: tendinitis in the shoulder, elbow, forearm, wrist, and Achilles tendon. These are possibly caused by physical strain when manually moving loads for a prolonged period of time and in places that impede workers from properly positioning themselves. We note that tendinitis among dockworkers occurs in other sites besides those described in the literature(2), such as the case of vessel guards, who's knees and ankles are the sites affected. Hence, there is the involvement of workers who virtually work the entire shift in the vertical position checking the boarding and disembarking of people, as well as the movement of goods on gangways, ramps, decks, platforms, in holds and other areas of the vessel ${ }^{(5)}$.

This study's results corroborate those of an investigation ${ }^{(17)}$ that assessed workers from different professions, such as seamstresses and hairdressers,

\footnotetext{
* Lashing cargo is intended to secure or bind the cargo in the vessels' holds or decks to avoid damage due to the sea's movements(16).
} 
construction workers, domestic workers, farmers, and security workers. The authors identified tendinitis of the supraspinatus tendon as the condition that most frequently led to sick leave, emphasizing the economic and social consequences arising from it. Because tendinitis is a painful manifestation, it leads to an incapacity to work and consequent lack of motivation to perform productive activities ${ }^{(17)}$.

Neck pain was another condition that stood out among dockworkers. Also known as tension neck syndrome or myofascial pain syndrome, it affects the muscles of the scapular or cervical region, causing intense pain in the vertebral column; it can also affect the cervical, dorsal, and lumbar portions ${ }^{(2)}$. There are factors that predict the prognosis of this disease in the context of dock work, such as is identified in a study(18) that verified potential association among neck pain, being older than 40 years of age, and the concomitant presence of lower back pain and headache in the worsening of neck pain prognosis over a short period of treatment(18). Under these conditions, dockworkers' productivity decreases and, as a consequence, their income is also reduced because they cannot apply for a job opportunity.

Based on the observed characteristics, we believe that dockworkers tend to develop neck pain due to the activities they perform. Therefore, multidisciplinary clinical actions are needed to prevent the onset and worsening of neck pain among these workers.

The limitation of this study is in regard to secondary data, which enabled only a partial view of the studied situation. However, the results obtained can support future studies and interventions in the field of occupational health nursing.

\section{Conclusions}

Musculoskeletal diseases affect workers in the different activities existing in dock work, highlighting that the characteristics inherent to the development of productive activities influence the onset or worsening of morbid conditions in the case of these workers.

The most frequent pathologies in this study include lower back pain, tendinitis and neck pain, whose symptomology should be prevented or mitigated through multidisciplinary, intervening and evaluative actions to improve working conditions and, consequently, positively influencing the quality of life of dockworkers.

The use of secondary data, which was not originally collected with an academic purpose, did not enable a thorough evaluation. The use of records from the
Occupational Health Outpatient Clinics may not reflect the extent of the whole problem because it would require workers to seek health care in situations that may be interpreted as inherent to work, in addition to the ability of medical professionals to recognize them. In this context, we suggest valid and reliable studies to test other data collection instruments, such as those in which workers either acknowledge themselves as affected by musculoskeletal diseases or not.

\section{References}

1. Murofuse NT, Marziale MHP. Doenças do sistema osteomuscular em trabalhadores de enfermagem. Rev. Latino-Am. Enfermagem. maio-junho 2005;13(3):364-73. 2. Ministério da Saúde (BR). Doenças relacionadas ao trabalho: manual de procedimentos para os serviços de saúde. Brasília (DF): Ministério da Saúde; 2001.

3. Díaz MDCM, Marziale MHP, Robazzi MLCC, Freitas FCT. Lesiones osteomusculares en trabajadores de un hospital mexicano y la ocurrencia del ausentismo. Cienc Enferm. 2010;16(2):35-46.

4. Schein D, Lima MLP. Uma metodologia para o dimensionamento de frota de rebocadores em terminais portuários: uma aplicação ao Porto do Rio Grande. Pesqui Operacional Desenvol. 2010;2(2):119-39.

5. Lei n. 8630, de 25 de fevereiro de 1993 (BR). Dispõe sobre o regime jurídico da exploração dos portos organizados e das instalações portuárias e dá outras providências. (Lei dos Portos). Diário Oficial da União, Brasília; 26 fev 1993.

6. Soares JFS, Cezar-Vaz MR, Mendoza-Sassi RA, Almeida TL, Muccillo-Baisch AL, Soares MCF, Costa VZ. Percepção dos trabalhadores avulsos sobre os riscos ocupacionais no Porto do Rio Grande, Rio Grande do Sul, Brasil. Cad Saúde Pública. 2008;24(6):1251-9.

7. Cavalcante FFG, Gomes ACN, Nogueira FRA, Farias JLM, Pinheiro JMR, Albuquerque $\mathrm{E}$, et al. Estudo sobre os riscos da profissão de estivador do Porto do Mucuripe em Fortaleza. Ciênc Saúde Colet. 2005; 10 Suppl: 101-10.

8. Cezar-Vaz MR, Soares JFS, Almeida MCV, Cardoso LS, Bonow CA. Doenças relacionadas ao trabalho autorreferidas por trabalhadores portuários avulsos. Ciênc Cuid Saúde. 2010;9(4):774-81.

9. Magnago TSBS, Lisboa MTL, Griep RH, Kischhof ALC, Guido, LA. Aspectos psicossociais do trabalho e distúrbio musculoesquelético em trabalhadores de enfermagem. Rev. Latino-Am. Enfermagem. [periódico na Internet]. 2010 [acesso 13 ago 2010]; 18(3):429-35. Disponível em: http://www.scielo.br/pdf/rlae/v18n3/pt_19.pdf 
10. Magnago TSBS, Lisboa MTL, Griep RH. Trabalho da enfermagem e distúrbio musculoesquelético: revisão das pesquisas sobre o tema. Esc Anna Nery. 2008;12(3):560-5.

11. Barboza MCN, Milbrath VM, Bielemann VM, Siqueira $\mathrm{HCH}$. Doenças osteomusculares relacionadas ao trabalho (DORT) e sua associação com a enfermagem ocupacional. Rev Gaúcha Enferm. 2008;29(4):633-8.

12. Paddan GS, Griffinm MJ. Evaluation of wholebody vibration in vehicles. J Sound Vibration. 2002;253(1):195-213.

13. Pinto FM, Silva EB, Knoplich J, Bacelar SC, Bertoni G, Dantas EHM. A Reeducação Dinâmica Muscular no Equilíbrio Postural e na redução da lombalgia em trabalhadores industriais. Mundo da Saúde. 2010;34(2):192-9.

14. Salvador D, Neto PED, Ferrari FP. Aplicação de técnica de energia muscular em coletores de lixo com lombalgia mecânica aguda. Fisioter Pesqui. 2005;12(2):20-7.

15. Moraes MVG. Sistematização da Assistência de Enfermagem em Saúde do Trabalhador - Instrumentos para coleta de dados direcionados aos exames ocupacionais da NR7 e à exposição aos agentes ambientes. São Paulo (SP): Iátria; 2008.

16. Ministério do Trabalho e Emprego (BR). Secretaria de Inspeção do Trabalho - SIT. Manual do Trabalho Portuário e Ementário. Brasília (DF): TEM; 2001.

17. Almeida JS, Carvalho G Filho, Pastre CM, Lamari NM, Pastre EC. Afecção do tendão supraespinal e afastamento laboral. Ciênc Saúde Coletiva. 2008;13(2):517-22.

18. Hoving JL, Vet HCW, Twisk JWR, Deville WLJM, Windt DVD, Koes BW, et al. Prognostic factors for neck pain in general practice. Pain. 2004;110:639-45. 